\title{
Split-Hand/Foot Malformation Type 1
}

National Cancer Institute

\section{Source}

National Cancer Institute. Split-Hand/Foot Malformation Type 1. NCI Thesaurus. Code C75045.

Split-hand/foot malformation mapped to chromosome 7q21.3 